hagazig J. Agric. Res., Vol. 43 No. (3) 2016

\title{
UTILIZATION OF MODERN TECHNIQUES FOR PRODUCING
} MOZZARELLA CHEESE

\author{
Tamer M. El-Nagdy ${ }^{*}$, M.M. Morad and M.K. Afify \\ Agric. Eng. Dept., Fac. Agric., Zagazig Univ., Egypt
}

\begin{abstract}
The present study was carried out to compare three different methods for producing three types of mozzarella cheese (natural, analogue and mix mozzarella cheeses). The main experiments were conducted under four steam pressures of $50,100,150$ and $200 \mathrm{kPa}$ and four processing temperatures of $65,72,75$ and $80{ }^{\circ} \mathrm{C}$. Evaluation of the three methods for producing mozzarella cheese was conducted taking into consideration productivity, melting, stretching, energy requirements and operational cost. The obtained data reveal the following important points: Manufacturing of analogue and mix mozzarella cheeses increased productivity and decreased both of specific energy and operational cost comparing with manufacturing of natural mozzarella cheese. Final product quality after manufacturing mix and natural mozzarella cheese are approximately similar and very close to the standard quality guidelines (standard limits). Maximum productivity values and minimum energy and cost were achieved in the case of manufacturing analogue, mix and natural mozzarella cheeses under conditions of $100 \mathrm{kPa}$ steam pressure and $72{ }^{\circ} \mathrm{C}$ processing temperature.
\end{abstract}

Key words: Analogue, mozzarella, operational cost, processing temperature

\section{INTRODUCTION}

Mozzarella cheese is a soft, unripened cheese variety of the pasta filata family which had its origin in the Buttipaglia region of Italy. The finished cheese is white, soft with a very lively sheen surface and has a unique property called stretchability to form fiber or strings when it is hot, therefor it is considered the most suitable cheese variety as a topping on pizza. Worldwide, cheese is a major agricultural product. According to the food and agricultural organization, over 20 million megagrams of cheese was produced worldwide. This is about 3 $\mathrm{kg}$ for each person on earth. The largest producer of cheese in the world is USA, this production is constituting $26 \%$ of world production (5162730 teragram). Mozzarella cheese located at the top types, Egypt is located at the eight from the top 10 cheese producer countries in the world, accounting for 644.500 teragram.

\footnotetext{
Corresponding author: Tel. : +201222213351
}

E-mail address: t.elnagdy99@gmail.com
Anonymous (1981) stated that cheese substitutes or analogues, are products in which some or all of the milk fat has been replaced by vegetable oils. They have the following advantages: can be tailored to a specific design since each component is added separately; have the advantage of dramatically lower levels of cholesterol; have an enormous price advantage over their 'natural' counterparts; and product consistency in colour, flavour and texture.

Ennis and Mulvihill (1997) mentioned that the importance of cheese analogues has increased due to both the desire to reduce the cost of cheese products and an increase in consumer demands for cheese and cheese-containing convenience foods. Aspects considered include: advantages of cheese analogues; functional characteristics of mozzarella analogues; composition of cheese analogues; emulsification in cheese analogues; caseins and caseinates in cheese analogues; role of emulsifying salts in manufacture; types of fats for the fat phase of 
cheese analogues; other ingredients; use of proteins other than casein in manufacture; starches and other hydrocolloids; processes used in manufacturing cheese analogues; and future developments.

Ferrari et al. (2003) examined the production process for mozzarella cheese with the aim of reducing costs and improving process efficiency. The most significant processing stages were determined to be forming and cooling. On the basis of the analysis, a cycle simplification was suggested which would decrease process times and complement production resources, consequently reducing production costs. In order to achieve this objective, a prototype stretching-forming extruder for mozzarella cheese was designed. Results of preliminary tests with this extruder were highly satisfactory with regard to use of materials and costs. The forming machine used in the conventional process was eliminated, and cooling time was reduced by approx., 10-folds, with resultant savings in use of refrigerant water. It is concluded that the proposed process modification for mozzarella cheese could reduce production costs by approx. $20 \%$.

Karimah (2008) produced five types of mozzarella cheese analogues using palm-based products, including bleached, deodorized palm oil (PO), palm olein (POo), palm kernel oil (PKO), palm stearin (POS) and a blend comprising 30\% PO and 70\% palm kernel olein. The changes in colour of mozzarella analogues before and after baking were compared with a control commercial mozzarella sample.

Gao et al. (2010) standardized a process for manufacture of mozzarella cheese analogue (MCA) using rennet casein and plastic cream as protein and fat sources, respectively. The formulation comprised of $25 \%$ plastic cream ( $72 \%$ fat), $27 \%$ rennet casein along with $3 \%$ trisodium citrate as emulsifying salt, $2 \%$ maltodextrin as binder, $0.55 \%$ lactic acid as $\mathrm{pH}$ regulator, $1 \%$ common salt for seasoning, $1 \%$ mozzarella cheese bud as flavouring and $40.4 \%$ water. The process involved (a) dissolving the dry mixture of casein, maltodextrin, flavouring and common salt in hot emulsifying salt solution, (b) incorporation of half the quantity of acid solution in casein-maltodextrin dough, followed by addition and emulsification of plastic cream, and (c) addition of remaining half of the acid solution and heating the mass to 80 ${ }^{\circ} \mathrm{C}$ until a plastic cheese mass was obtained. The analogue was shaped in ball form, cooled and packaged in polyethylene bag.

Guinee (2011) stated that cheese analogues (CAs) as cheaper alternatives to cheese and processed cheese products (PCPs). They are prepared by blending various edible oils / fats, proteins (e.g., powders), water, emulsifying salts (ES), and other ingredients (e.g., cheese flavors, starches) into a smooth homogeneous blend with the aid of heat and mechanical shear. They may be arbitrarily classified as substitutes or imitations, in which either milk fat or milk protein or both are partially or wholly replaced by nonmilk-based components, principally of vegetable origin. The primary stabilization agent in CAs is casein and/or para-casein which in the presence, of an ES is converted to a functional protein that binds water and emulsifies oil during processing. The initial solubility, $\mathrm{pH}$, and mineral composition of milk proteins significantly influence the resultant CAs.

Therefore, the objectives of the present study are to:

- Compare between three different methods for producing three different types of mozzarella cheese (natural, analogue and mix)

- Optimize some different operating parameters affecting mozzarella cheese production.

- Minimize both energy and cost in all stages of mozzarella cheese production.

\section{MATERIALS AND METHODS}

Field experiments were carried out at Green land Group for food industries, area 106 industrial zone B3-10 ${ }^{\text {th }}$ of Ramadan City, Sharkia Governorate, Egypt through tow seasons of 2014-2015.

\section{Materials}

\section{Materials Used for Producing Mozzarella Cheese}

Table 1 shows the materials used for producing the three types of mozzarella cheese (Natural, Analogue and Mix). 
Table 1. Materials used for producing three types of mozzarella cheese

\begin{tabular}{lccc}
\hline Row material & Natural & Analogue & Mix \\
\hline Cow's milk, kg & 9000 & 0 & 0 \\
Acetic acid, kg & 33 & 0 & 0 \\
Rennet, g & 180 & 0 & 0 \\
Milk powder concentrate, kg & 25 & 0 & 0 \\
Water, kg & 4000 & 72.05 & 40.55 \\
Rennet casein, kg & 0 & 33 & 33 \\
Skimmed milk powder, g & 0 & 500 & 500 \\
Cream flavour, g & 0 & 500 & 500 \\
Palm oil, kg & 0 & 37.5 & 0 \\
Citric acid, g & 0 & 750 & 750 \\
Tri-sodium citrate, kg & 0 & 1.2 & 1.2 \\
Sodium chloride, $\mathbf{k g}$ & 0 & 2.5 & 2.5 \\
Modified Potato starch, kg & 0 & 2 & 2 \\
Cream 50\%fat, kg & 0 & 0 & 69 \\
Produced cheese, $\mathbf{k g}$ & 810 & 150 & 150 \\
\hline
\end{tabular}

\section{Equipment Specifications}

Equipment specifications used for producing natural mozzarella cheese

\section{Plats heat exchanger}

Plats heat exchanger was used to pasteurize the milk to $72^{\circ} \mathrm{C} / 15 \mathrm{sec}$.

\section{Homogenizer}

Homogenizer was used to homogenize the milk at $50 \mathrm{kPa}$,

\section{Separator}

Separator was used to separate part of the cream of the milk.

\section{Stainless tank}

Stainless tank was used to keep the pasteurized milk.

\section{Stainless receiving tank}

Stainless receiving tank model CF80 was used to acidify, heat and coagulation the milk by adding acetic acid and rennet.

\section{Maturation tank}

Maturation tank model DMC4 was used to drain the whey which produced from coagulation the milk and keep the curd until transfer it to cook.

\section{Auger curd transport}

Auger curd transport was used to transport the curd which produced from coagulation to the cooker.

\section{Cooker and stretcher}

Cooker and stretcher model combi 1200 tra-o was used to cook the curd by hot water.

\section{Molder}

Molder model HG1250SX was used to mold the cooked curd, and discharge it to the cooling brine.

\section{Cooling brine}

Cooling brine was used to cool and salt the mold cheese, before transfer it to the refrigerator. 


\section{Refrigerator}

Refrigerator was used to cool and keep the mold cheese at $4^{\circ} \mathrm{C}$ for 2: 4 days before shredded the cheese.

\section{Equipment specifications used for producing} analogue and mix mozzarella cheese

\section{Cooker}

Cooker model DM18/150 was used to mix, homogenize and heat all the ingredients of analogue mozzarella cheese, its type is Dima.

\section{Refrigerator}

Refrigerator was used to cool and keep the mold cheese at $4{ }^{\circ} \mathrm{C}$ for 2: 4days before shredded the cheese.

\section{Measuring Instruments}

\section{PH meter}

An electronic $\mathrm{pH}$ meter was used to measure the $\mathrm{pH}$ degree on the milk and the cheese.

\section{Gerber centrifuge}

Centrifuge was used to measure the fat concentrate in the milk and the cheese.

\section{Oven (INDER)}

An electronic oven was used to cook the pizza at $250^{\circ} \mathrm{C} / 6 \mathrm{~min}$.

\section{Fork}

Stainless fork was used to measure stretch degree of the cooked cheese.

\section{Kern balance}

An electronic balance was used to measure the mass of the additives (with accuracy of \pm $0.001 \mathrm{~kg}$ ).

\section{Ruler}

Ruler was used to measure the length of measure stretch degree of the cooked cheese.

\section{Mettler toledo}

Mettler toledo was used to measure the moisture content of the cheese.

\section{Digital refractometer}

Refractmeter was used to measure total solids concentrate in the whey and the water which washed the curd.

\section{Twin sensor}

Twin sensor was used to measure antibiotic in the milk.

\section{Velpscientifca}

Velpscientifc was used to measure protein concentrate.

\section{Methods}

Experiments were carried out to compare three different methods for producing three types of mozzarella cheese (natural, analogue and mix mozzarella cheese).

\section{The Experimental Conditions}

The main experiments were conducted under the following conditions:

- Three different methods for producing three different types of mozzarella cheese (natural, analogue and mix)

- Three different types of mozzarella cheese (natural, analogue and mix) from standard quality view.

- Four different steam pressures of 50, 100, 150 and $200 \mathrm{kPa}$.

- Four different processing temperatures of 65 , 72,75 and $80^{\circ} \mathrm{C}$.

\section{Methods of mozzarella cheese production}

Figs. 1, 2, 3, 4 and 5 show flow chart of the three methods and equipment used for producing the three types of mozzarella cheese.

\section{Measurements}

Evaluation of the three methods of manufacturing mozzarella cheese was conducted taking into consideration the following indicators:

\section{Productivity}

$$
\mathrm{P}=\frac{\mathrm{p}}{\mathrm{t}}, \mathrm{kg} / \mathrm{h}
$$

Where

$\mathrm{p}=$ Production of mozzarella cheese, $\mathrm{kg}$;

$\mathrm{t}=$ Production time of mozzarella cheese, $\mathrm{hr}$. 


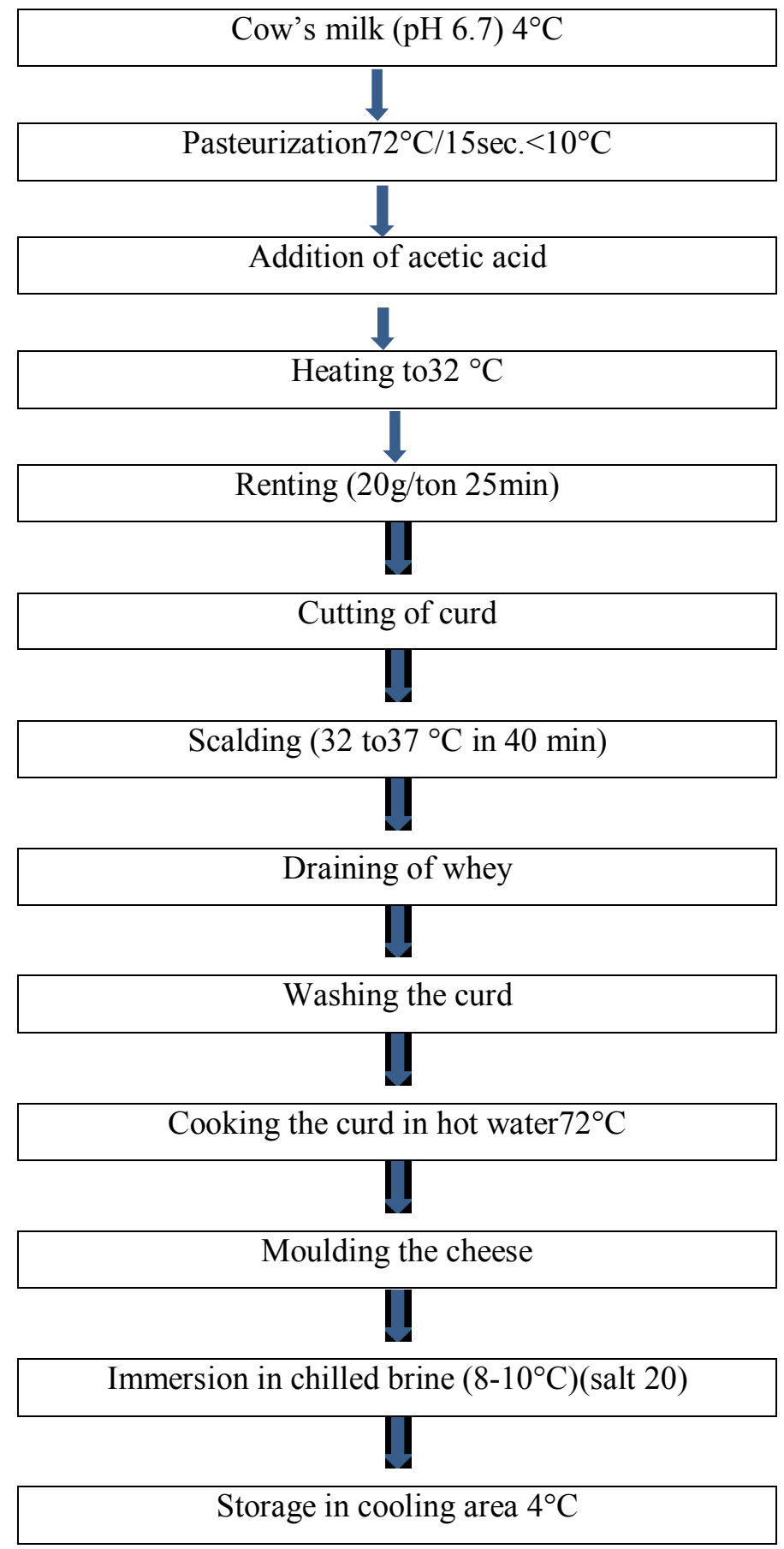

Fig. 1. Flow chart of natural mozzarella cheese production 


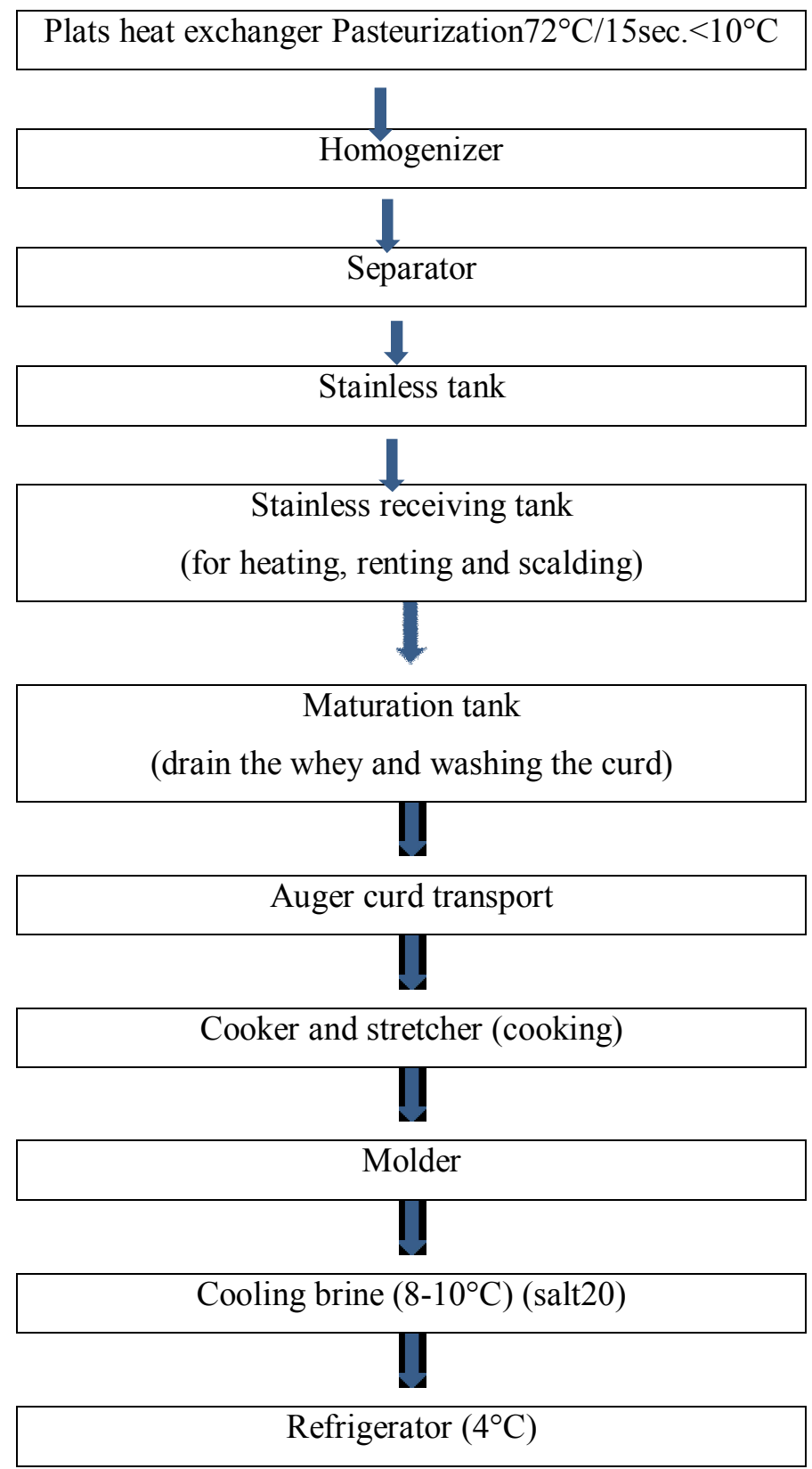

Fig. 2: Flow chart of equipments used in natural mozzarella cheese production 


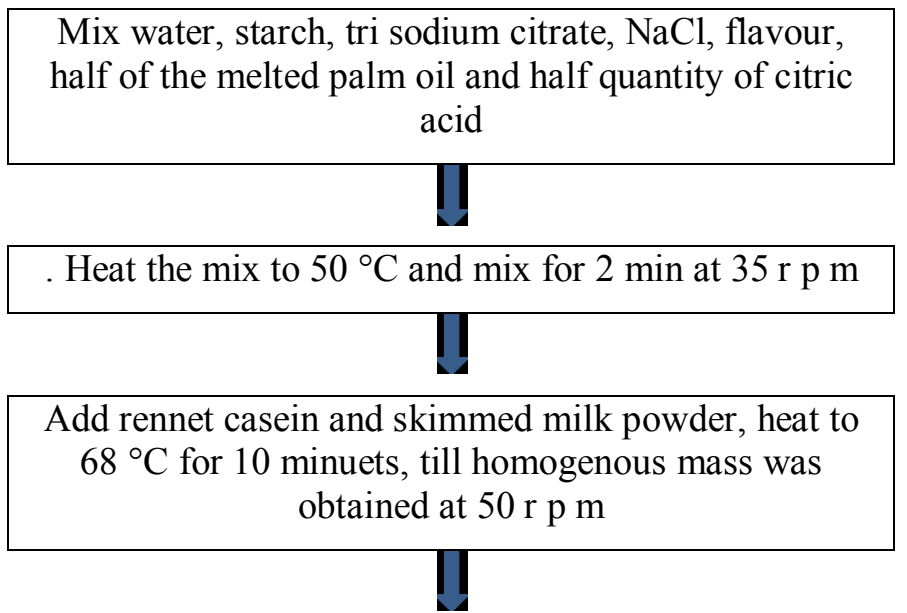

Add the other half melted palm oil and the other half of citric acid; heat the mass to $72{ }^{\circ} \mathrm{C}$ for 10 minutes at 60 $\mathrm{rpm}$

Fill the cheese in creates keep it in cooling area $4^{\circ} \mathrm{C}$

Fig. 3: Flow chart of analogue mozzarella cheese production

Mix water, starch, tri sodium citrate, $\mathrm{NaCl}$, flavour, half of the melted cream and half quantity of citric acid

. Heat the mix to $50{ }^{\circ} \mathrm{C}$ and mix for $2 \mathrm{~min}$ at $35 \mathrm{r} \mathrm{p} \mathrm{m}$

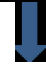

Add rennet casein and skimmed milk powder, heat to $68^{\circ} \mathrm{C}$ for 10 minuets, till homogenous mass was obtained at $50 \mathrm{r} \mathrm{p} \mathrm{m}$

Add the other half melted cream and the other half of citric acid; heat the mass to $72{ }^{\circ} \mathrm{C}$ for 10 minutes at 60 $\mathrm{rpm}$

Fill the cheese in creates keep it in cooling area $4^{\circ} \mathrm{C}$

Fig. 4. Flow chart of mix mozzarella cheese production

Mixing, heating. Homogenizing, and filling the cheese

Refrigerator $\left(4^{\circ} \mathrm{C}\right)$

Fig. 5: Flow chart of analogue and mix mozzarella cheese production 


\section{Stretchability}

Stretchability was measured after four days of storage using a fork test (Gunasekaran and Ak, 2003), after baking mozzarella cheese on a pizza crust. Cheese samples were mechanically shredded, A $30-\mathrm{cm}$ frozen pizza crust was thawed, $16 \mathrm{~g}$ of tomato pizza sauce was spread over it, and then it was covered with $300 \mathrm{~g}$ of shredded cheese. The pizza was baked in a forced-air convection oven for $6 \mathrm{~min}$ at $250^{\circ} \mathrm{C}$. One minute after baking, a stainless steel fork was inserted into the cheese, then lifted vertically and the distance at which the cheese could be lifted before breaking was measured. Extent of stretch was measured from three different places on the pizza.

\section{Meltability}

Meltability may be defined as the ease with cheese flows or spreads upon heating. In general terms, meltability is the capacity of cheese particles to flow together and form a uniform continuous melt .There are many methods available to study the phenomenon of cheese meltability. The method proposed by (Wang et al., 1998) in this test, a plug of cheese(7-mm thickness and 30-mm diameter), placed in aluminum plate, is heated in an oven set at $232^{\circ} \mathrm{C}$ for $5 \mathrm{~min}$. The melted cheese is cooled for $30 \mathrm{~min}$. and the largest diameter of spread is taken as an estimate the percentage of its meltability

\section{Specific energy}

The following formula was used to estimate the required power.

$$
\mathrm{P}=\sqrt{3} \times \cos \phi \times \mathrm{I} \times \mathrm{V}
$$

Where

$$
\begin{aligned}
& \mathrm{P}=\text { required power, } \mathrm{kW} \\
& \mathrm{I}=\text { current intensity, Ampere } \\
& \mathrm{V}=\text { voltage, }(380 \mathrm{v}) \\
& \cos \phi=0.7
\end{aligned}
$$

Specific energy $=\frac{\text { required power }}{\text { productivity }}, \mathrm{kW} \cdot \mathrm{hr} / \mathrm{kg}$

\section{Operational cost}

Operational cost $=\frac{\text { Hourly cost }}{\text { productivity }}$, L.E $/ \mathrm{kg}$.

The hourly cost was estimated according to the conventional method of estimating both fixed and variable costs.

\section{RESULTS AND DISCUSSION}

The discussion will cover the obtained results under the following heads:

\section{Mozzarella Cheese Productivity}

Representative mozzarella cheese productivity versus processing temperature are given for the three types of mozzarella cheese (analogue, natural and mix) under various steam pressures in Fig. 4.

Results show that mozzarella cheese productivity values were more pronounced as processing temperature increased up to $72^{\circ} \mathrm{C}$. Any further increase in processing temperature more than 72 up to $80^{\circ} \mathrm{C}$, mozzarella cheese productivity will decrease. Results show that analogue mozzarella cheese productivity values were more pronounced as steam pressure increased up to $100 \mathrm{kPa}$. Any further increase in steam pressure more than 100 up to $200 \mathrm{kPa}$, mozzarella cheese productivity will decrease.

The obtained results show that increasing processing temperature from 65 to $72^{\circ} \mathrm{C}$, measured under various steam pressure of 50 , 100,150 and $200 \mathrm{kPa}$, increased productivity from 298.4 to 299.4 , from 299 to 300 , from 298.2 to 299.4 from 298.1 to $298.9 \mathrm{~kg} / \mathrm{hr}$ respectively for analogue mozzarella cheese. Meanwhile increased productivity from 134.2 to 134.6, from 134.6 to 135 , from 134.3 to 134.7 and from 134.1 to $134.5 \mathrm{~kg} / \mathrm{hr}$ for natural mozzarella cheese. Also increased productivity from 298.6 to 299.5 , from 299.2 to 300 , from 298.7 to 299.5 and from 298.2 to $299 \mathrm{~kg} / \mathrm{hr}$ for mix mozzarella cheese. Any further increase in processing temperature more than $72^{\circ} \mathrm{C}$ up to $80^{\circ} \mathrm{C}$, productivity decreased from 299.4 to 297.5 , from 300 to 297.4 , from 299.4 to 297.3 and from 298.9 to $297.1 \mathrm{~kg} / \mathrm{hr}$ for analogue mozzarella cheese. Meanwhile decreased productivity from 134.6 to 132.6 , from 135 to 132.4 , from 134.7 to 132.2 , and from 134.5 to 


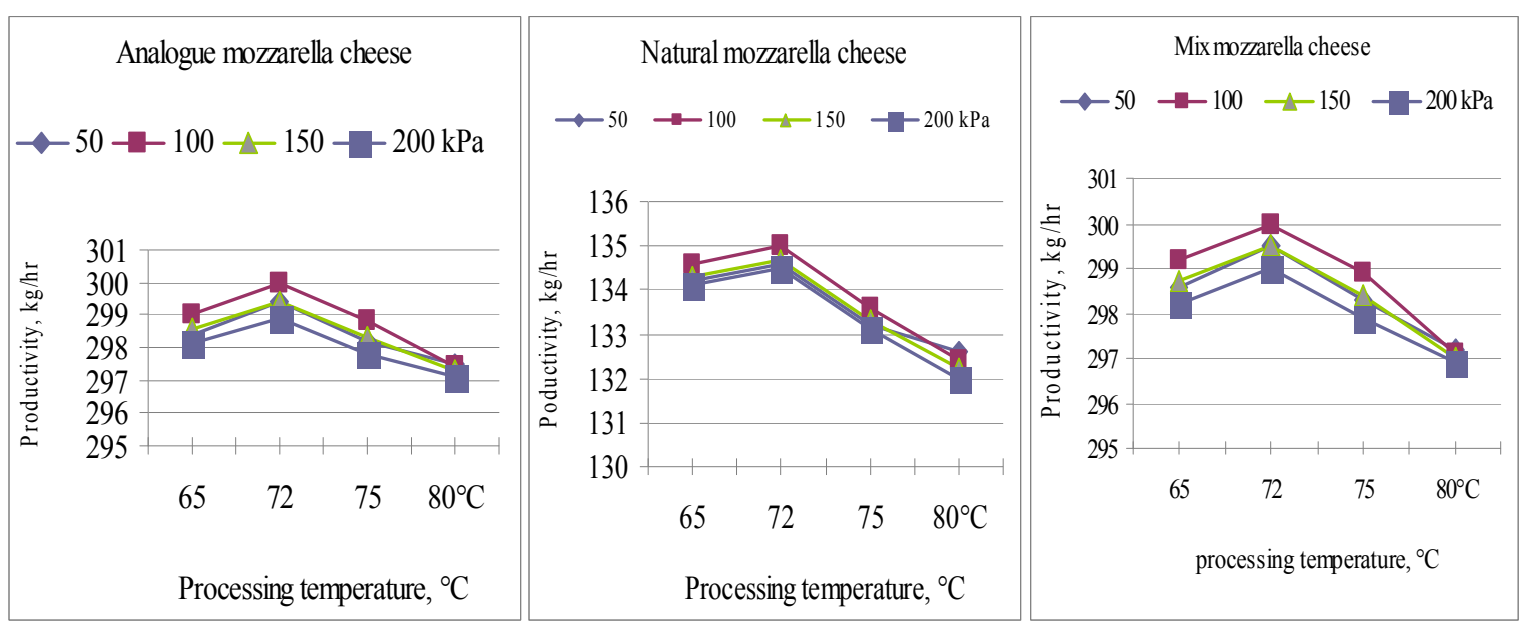

Fig. 4. Effect of processing temperature on the productivity of analogue, natural and mix mozzarella cheese

$132 \mathrm{~kg} / \mathrm{hr}$., for natural mozzarella cheese. Also decreased productivity from 299.5 to 297.2 , from 300 to 297.1, from 299.5 to 297 and from 299 to $296.9 \mathrm{~kg} / \mathrm{hr}$ for mix mozzarella cheese under the same previous conditions.

The decrease in mozzarella cheese productivity at the processing temperature of $65^{\circ} \mathrm{C}$ and steam pressure of $50 \mathrm{kPa}$ may be attributed to that all ingredients of the cheese take more time to homogenized together, caused losses in fat and moisture and produced stiff chees, with short and inelastic string, with tendency to burning instead of fusing cheese.

The decrease in mozzarella cheese productivity at the processing temperature of $80^{\circ} \mathrm{C}$ and steam pressure of $200 \mathrm{kPa}$ is due to cook all the ingredients of the cheese fastly, resuling in separations of the water and fat from the cheese content that produced stiff cheese, with short and inelastic strings, with tendency to burning instead of fusing cheese. The processing temperature $72^{\circ} \mathrm{C}$ is suitable to cook and homogenize all the ingredients of the cheese together until become one mass.

Results show that analogue and mix mozzarella cheese productivity values were more than natural mozzarella cheese productivity under the same conditions due to the total time which used to produce natural mozzarella cheese.

\section{Mozzarella Cheese Meltability}

Representative mozzarella cheese meltability versus processing temperature are given for the three types of mozzarella cheese (analogue, natural and mix) under various steam pressures in Fig. 5.

Results show that mozzarella cheese meltability values increasd as processing temperature increased up to $72^{\circ} \mathrm{C}$. Any further increase in processing temperature more than 72 up to $80^{\circ} \mathrm{C}$, mozzarella cheese meltability will decrease.

Results also show that analogue mozzarella cheese meltability values incresed as steam pressure increased up to $100 \mathrm{kPa}$. Any further increase in steam pressure more than 100 up to $200 \mathrm{kpa}$, mozzarella cheese meltability will decrease.

The obtained results show that increasing processing temperature from 65 to $72^{\circ} \mathrm{C}$, measured under various steam pressures of 50, 100, 150 and $200 \mathrm{kPa}$, increased meltability from 72.7 to 96.4 , from 75.1 to 98 , from 73.1 to 96.8 and from 71.5 to $95.6 \%$ respectively for analogue mozzarella cheese. Meanwhile increased meltability from 75.3 to 97.5 , from 78.2 to 100 , from 74.4 to 97.8 and from 73.1 to $96.4 \%$ for natural mozzarella cheese. Also increased meltability from 73.5 to 97 , from 76.2 to 99 , from 73.6 to 96.3 , and from 72.4 to 95.8\% for mix mozzarella cheese under the same previous conditions. Any further increase in processing temperature more than $72^{\circ} \mathrm{C}$ up to $80^{\circ} \mathrm{C}$, 


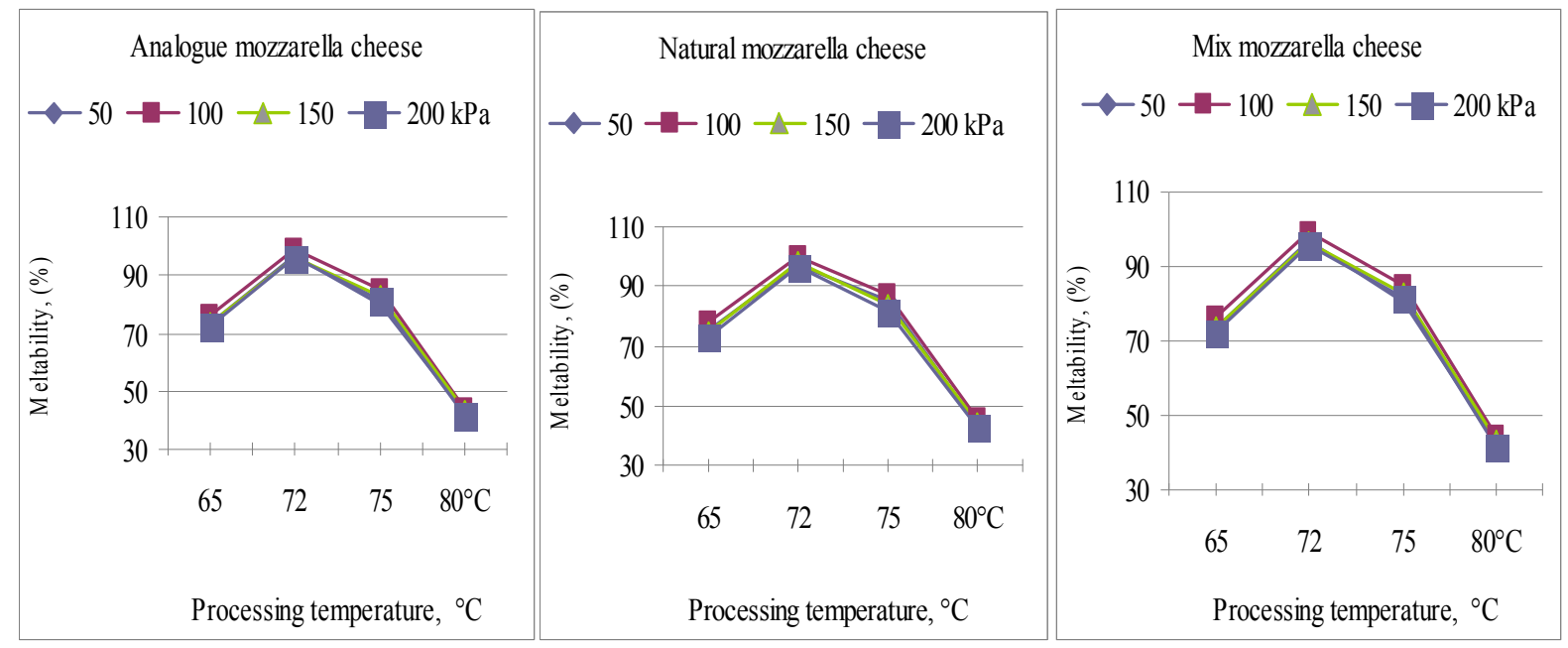

Fig. 5. Effect of processing temperature on the meltability of analogue, natural and mix mozzarella cheese

decreased meltability from 96.4 to 41.9 , from 98 to 43.1, from 96.8 to 42.6 , from 95.6 to $39.6 \%$ for analogue mozzarella cheese; from 97.5 to 43.6 , from 100 to 45.6 , from 97.8 to 44.3 and from 96.4 to $42.5 \%$; from 97 to 42.6 , from 99 to 44.2 , from 96.3 to 43.2 from 95.8 to $41.6 \%$ for mix mozzarella cheese under the same previous conditions.

The decrease in mozzarella cheese meltability at processing temperature of $65^{\circ} \mathrm{C}$ and steam pressure $50 \mathrm{kPa}$ is attributed to inherently melt well because of their decreased calcium content and this was further enhanced by the presence of fat that was not entrapped within the protein matrix. Relatively large amount of butterfat was present between the curd particles, and it appears that this fat acted as a lubricant when the cheese was heated, allowing the cheeses to flow rapidly at $65^{\circ} \mathrm{C}$.

Results showed that analogue mozzarella cheese meltability values were so similar to natural mozzarella cheeses with the same conditions this rate due to the same structure which used to content and build the matrix of fat and protein.

\section{Mozzarella Cheese Stretchability}

Representative mozzarella cheese strechability versus processing temperature are given for the three types of mozzarella cheese (analogue, natural and mix) under various steam pressures in Fig. 6.
Results showed that mozzarella cheese stretchability values increeased as processing temperature increased up to $72^{\circ} \mathrm{C}$. Any further increase in processing temperature more than 72 up to $80^{\circ} \mathrm{C}$, mozzarella cheese stretchability will decrease. Results show that mozzarella cheese stretchability values increased up to $100 \mathrm{kPa}$. any further increase in steam pressure more than 100 $\mathrm{kPa}$ up to $200 \mathrm{kPa}$, mozzarella cheese stretchability will decreas .

The obtained results show that increasing processing temperature from 65 to $72{ }^{\circ} \mathrm{C}$, measured under various steam pressures of $50,100,150$ and $200 \mathrm{kPa}$, increased strechability from 20.6 to 27.4, from 21.4 to 28.5 , from 20.8 to 28.1 and from 20.3 to $26.8 \mathrm{~cm}$, respectively for analogue mozzarella cheese. Also increased strechability from 21.6 to 28.6 , from 23.5 to 31 , from 22.4 to 29.1 and from 21.3 to $28.3 \mathrm{~cm}$ for natural mozzarella cheese; from 21.1 to 28.1 , from 22.1 to 30 , from 21.3 to 28.4 and from 20.9 to 27.2 $\mathrm{cm}$, respectively for mix mozzarella cheese under the same previous conditions. Any further increase in processing temperature more than 72 up to $80^{\circ} \mathrm{C}$, decreased strechability from 27.4 to 12.1, from 28.5 to 12.3 , from 28.1 to 12.1 and from 26.8 to $11.3 \mathrm{~cm}$ for analogue mozzarella cheese; from 28.6 to 13.1 , from 31 to 15.3 , from 29.1 to 13.3 , and from 28.3 to $12.2 \mathrm{~cm}$ for natural mozzarella cheese; from 28.1 to 12.5 , 


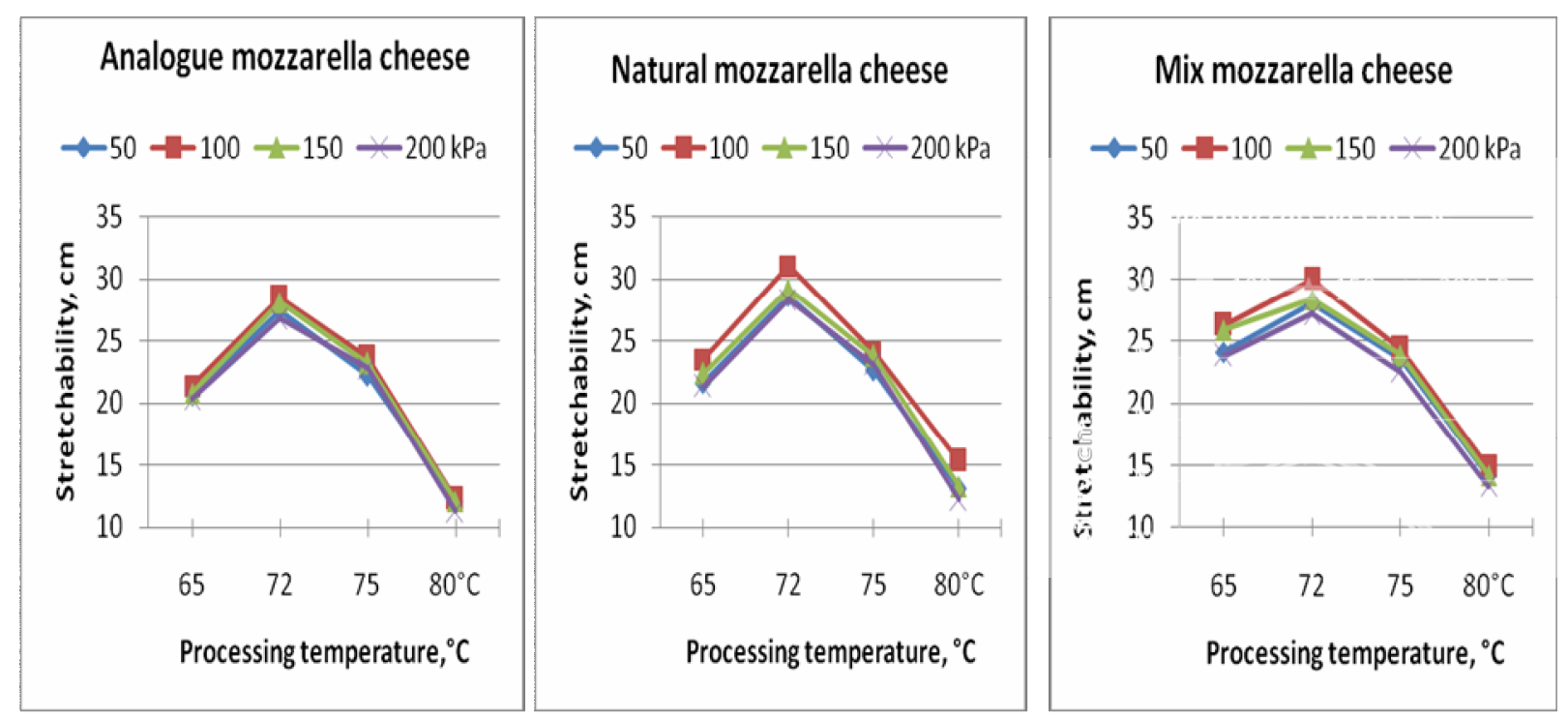

Fig. 6. Effect of processing temperature on the stretchability of analogue, natural and mix mozzarella cheese

from 30 to 14.8 , from 28.4 to 12.5 , and from 27.2 to $11.8 \mathrm{~cm}$ for mix mozzarella cheese under the same mentioned steam pressures, respectively.

Results show that analogue mozzarella cheese stretchability values were so similar to natural mozzarella cheese with the same condition due to the same structure which used to contents and build the matrix of fat and protein.

\section{Specific Energy for Producing Mozzarella Cheese}

Representative specific energy values versus processing temperature are given for the three types of mozzarella cheese (analogue, natural and mix) under various steam pressures in Fig. 7.

Results showed that specific energy values increased as processing temperature increased.

The obtained results show that increasing processing temperature from 65 to $80^{\circ} \mathrm{C}$, measured under various steam pressures of 50 , 100,150 and $200 \mathrm{kPa}$, increased specific energy from 18.55 to 18.64 , from 18.54 to 18.63 , from 18.6 to 18.69 and from 18.7 to $18.79 \mathrm{~kW} . \mathrm{hr} / \mathrm{kg}$ respectively for analogue mozzarella cheese. Meanwhile increased specific energy from 305.55 to 305.64 , from 305.5 to 305.59 , from 305.6 to 305.69 and from 305.7 to $305.8 \mathrm{~kW} . \mathrm{hr} /$ $\mathrm{kg}$ for natural mozzarella cheese; also increased specific energy from 18.55 to 18.64 , from 18.54 to 18.63 , from 18.6 to 18.69 and from 18.7 to $18.79 \mathrm{~kW} . \mathrm{hr} / \mathrm{kg}$, respectively for mix mozzarella cheese under the same previous conditions.

The increase in specific energy by increasing processing temperature is due to consuming more steam and time. Results show that specific energy for producing analogue, natural and mix mozzarella cheese values were too different under the same conditions due to the different time and power used in processing. Both analogue and mix mozzarella cheese processing consumed little energy compared to processing natural mozzarella cheese.

\section{Operational Cost for Producing Mozzarella Cheese}

Representative operational cost for producing mozzarella cheese versus processing temperature are given for the three types of mozzarella cheese (analogue, natural and mix) under various steam pressures in Fig. 8.

Results also show that operational cost values increased as processing temperature increased. Results show that operational values decreased as steam pressure increased up to 100 $\mathrm{kPa}$. Any further increase in steam pressure more than 100 up to $200 \mathrm{kPa}$, operational cost will increase. 

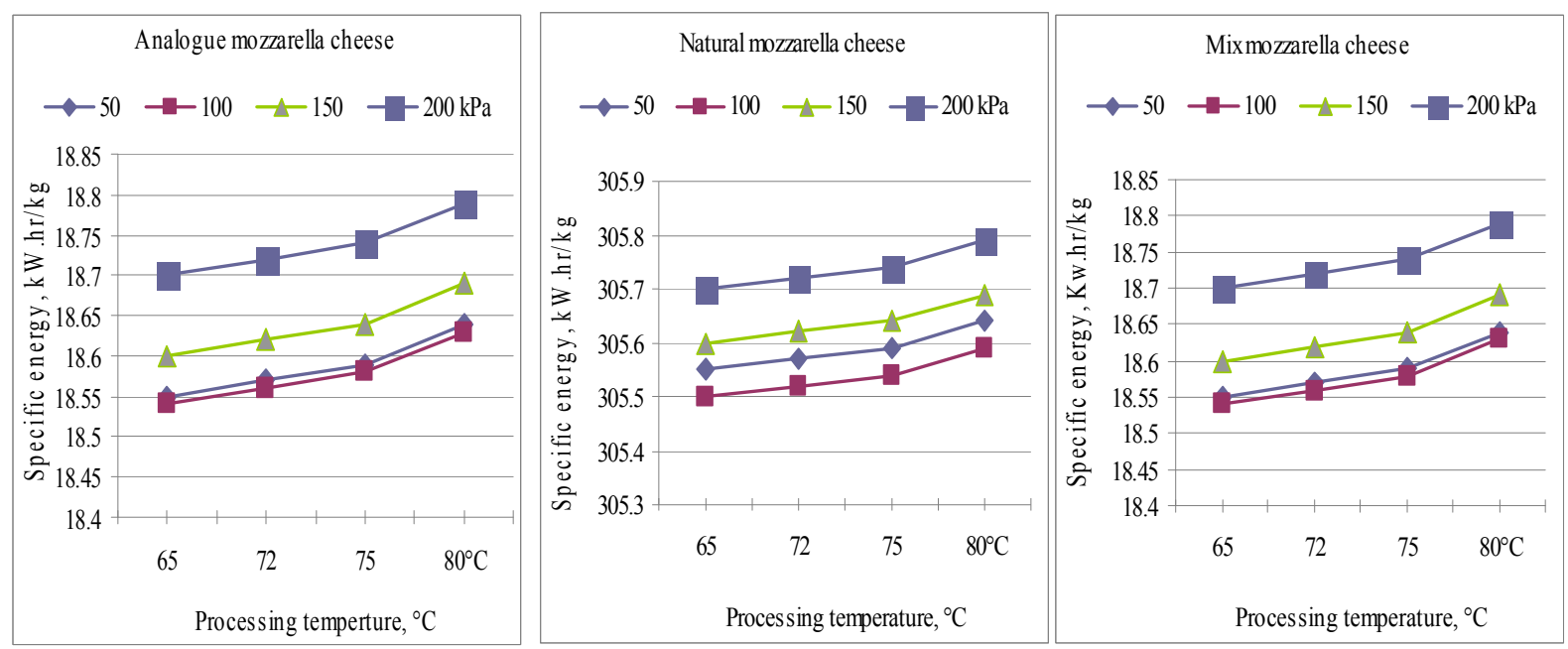

Fig.7. Effect of processing temperature on the specific energy for producing analogue, natural and mix mozzarella cheese

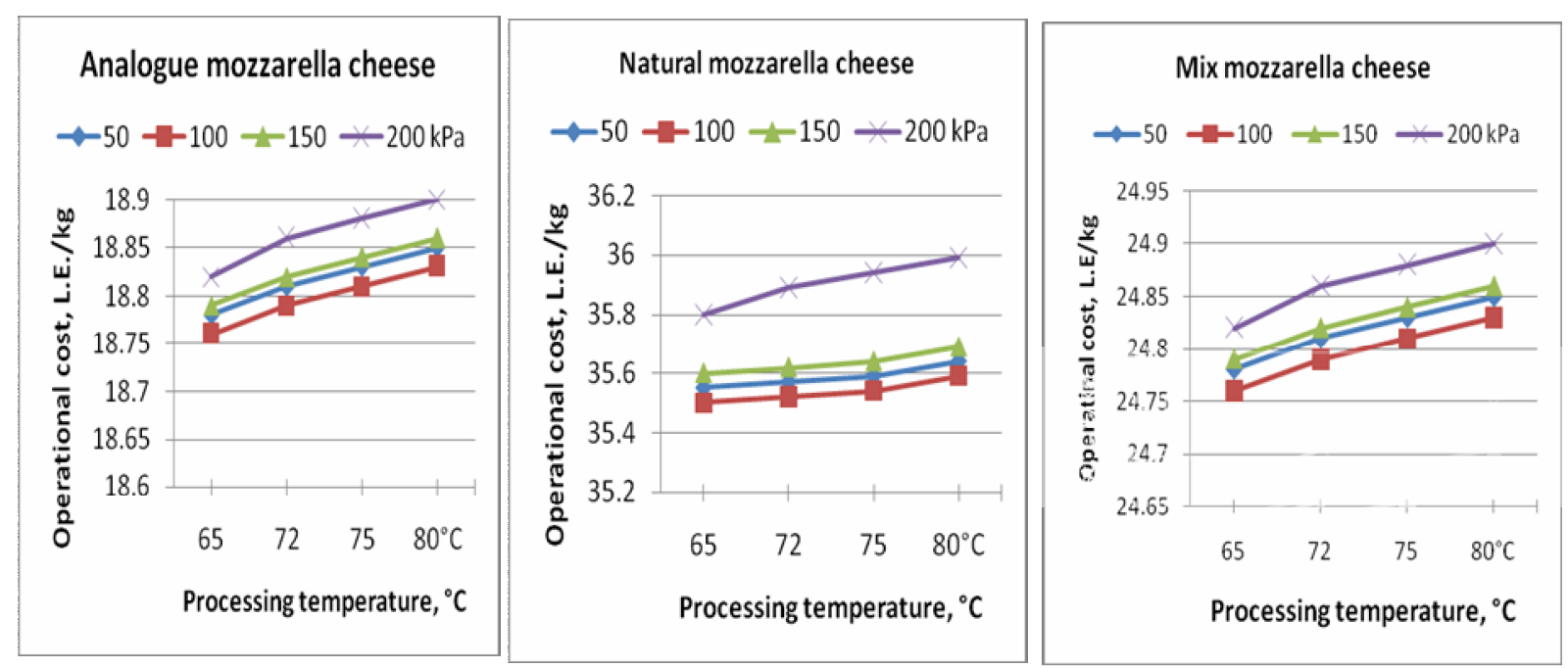

Fig.8. Effect of processing temperature on the operational cost for producing analogue, natural and mix mozzarella cheese

The obtained results show that increasing processing temperature from 65 to $80^{\circ} \mathrm{C}$, measured under various steam pressures of 50 , 100,150 and $200 \mathrm{kPa}$, increased operational cost from 18.78 to 18.85 , from 18.76 to 18.83 , from 18.79 to 18.86 and from 18.82 to $18.90 \mathrm{~L} . \mathrm{E} / \mathrm{kg}$ respectively for analogue mozzarella cheese. Also increased operational cost from 35.55 to 35.64 , from 35.50 to 35.59 , from 35.60 to 35.69 and from 35.80 to 35.99 L.E $/ \mathrm{kg}$ for natural mozzarella cheese; from 24.78 to 24.85 , from 24.76 to 24.83 , from 24.79 to 24.86 and from 24.82 to 24.90 L.E $/ \mathrm{kg}$ respectively for mix mozzarella cheese under the same previous conditions.

The increase in operational cost by increasing processing temperature is due to consuming more steam and time resulting in high cost. Results show that operational cost values for producing analogue, natural and mix mozzarella cheese were too different under the same conditions due to the different of row material, time and power used in processing. Both analogue and mix cheeses processing save processing cost compared to natural mozzarella cheese. 


\section{Product Quality}

In order to ensure a consistent, high quality product that it's safe for all uses, it important to develop quality guidelines for mozzarella cheese that is sold or given away. Representative physical, chemical, microbiological and rheological criteria are given for the three types of mozzarella cheese (analogue, natural and mix) under processing temperature $72^{\circ} \mathrm{C}$ and steam pressure $100 \mathrm{kPa}$ compared to the standard guidelines in Tables 2, 3, 4 and 5.

The obtained data in the tables show that the final mozzarella cheese quality of both natural and mix cheeses are approximately the same and very close to the standard guidelines. While analogue mozzarella cheese is somehow less in quality guidelines. so mix mozzarella cheese can be used instead of natural mozzarella cheese as it consumed less energy and cost during processing compared to natural mozzarella cheese.

\section{Conclusion}

The present study was carried out to compare three different methods for producing three different types of mozzarella cheese (natural, analogue and mix mozzarella cheeses).

The present study recommended the following:

1. Manufacturing of analogue and mix mozzarella cheese increased productivity and decreased both specific energy and operational cost comparing with manufacturing of natural mozzarella cheese.

2. Final product quality after manufacturing both mix and natural mozzarella cheese are approximately similar and very close to the standard quality guidelines (standard limits).

3. Maximum productivity values and minimum energy and cost were achieved during manufacturing both natural and analogue mozzarella cheese under conditions of 100 $\mathrm{kPa}$ steam pressure and $72^{\circ} \mathrm{C}$ processing temperature.

Table 2. Physical citeria of natural, analogue and mix mozzarella cheeses

\begin{tabular}{lcccc}
\hline \multicolumn{1}{c}{ Physical criteria } & Standard guidlines & Natural & Analogue & Mix \\
\hline Texture & Semi-hard & Semi-hard & Semi-hard & Semi-hard \\
Odour or flavour & $\begin{array}{c}\text { Dairy product taste. } \\
\text { Free for foreign }\end{array}$ & $\begin{array}{c}\text { Dairy product } \\
\text { taste. Free for } \\
\text { foreign }\end{array}$ & $\begin{array}{c}\text { Dairy product } \\
\text { taste. Free for } \\
\text { foreign }\end{array}$ & $\begin{array}{c}\text { Dairy product } \\
\text { taste. Free for } \\
\text { foreign }\end{array}$ \\
Colour & Yellowish or white & yellowish & white & yellowish \\
Energy per 100gm, kcal & $290-309$ & 300 & 295 & 298 \\
Taste & excellent & excellent & good & very good \\
\hline
\end{tabular}

Table 3. Chemical citeria of natural, analogue and mix mozzarella cheeses

\begin{tabular}{lcccc}
\hline Chemical criteria & Standard guidlines & Natural & Analogue & Mix \\
\hline Fat (\%) & $19.5-24$ & 22 & 25 & 23 \\
Moisture (\%) & $48-52$ & 51 & 48 & 50 \\
Dry matter (\%) & $52-48$ & 49 & 52 & 50 \\
pH (\%) & $5.2-6.2$ & 5.6 & 6.2 & 6.1 \\
Salt (\%) & $1-2$ & 1.7 & 1.7 & 1.7 \\
Protein (\%) & $18-22$ & 21 & 18 & 19 \\
\hline
\end{tabular}


Table 4. Microbiological citeria of natural, analogue and mix mozzarella cheeses

\begin{tabular}{lcccc}
\hline Microbiological criteria & Standard guidlines & Natural & Analogue & Mix \\
\hline Salmonella spp. & Absent & Absent & Absent & Absent \\
Listeria monocytogenes & Absent & Absent & Absent & Absent \\
Escherichia coli & Absent & Absent & Absent & Absent \\
Staphylococcus aureus & Absent & Absent & Absent & Absent \\
Yeast, cfu/g & $<400$ & $<400$ & $<400$ & $<400$ \\
Mould, cfu/g & $<10$ & $<10$ & $<10$ & $<10$ \\
Coliform, cfu/g & $<10$ & $<10$ & $<10$ & $<10$ \\
\hline
\end{tabular}

Table 5. Rheological citeria of natural, analogue and mix mozzarella cheeses

\begin{tabular}{lcccc}
\hline Rheological criteria & Standard guidlines & Natural & Analogue & Mix \\
\hline Stretch, cm & 31 & 31 & 28.5 & 30 \\
Melt,(\%) & $100 \%$ & $100 \%$ & $98 \%$ & $99 \%$ \\
Texture & Smooth & Smooth & Smooth & Smooth \\
Oiling & Surface sheen & Surface sheen & Surface sheen & Surface sheen \\
Break down & None & None & None & None \\
\hline
\end{tabular}

\section{REFERENCES}

Anonymous. (1981). Cheese substitutes. Food Processing Industry, 50 (600): 48-49.

Ennis, M.P. and D.M. Mulvihill (1997). Cheese analogues. Proceedings of the fifth cheese symposium, Teagasc Dublin, Ireland, 1-14.

Ferrari, E., M. Gamberi, R. Manzini, A. Pareschi, A. Persona and A. Regattieri (2003). Redesign of the mozzarella cheese production process through development of a micro-forming and stretching extruder system. J. Food Engin., 59 (1): 13-23.

Gao, Y.S., F.Z. Hong, C.X. Fei, L. Jiong, X.J. Li and X.X. Shu (2010). Optimization of process of analog mozzarella cheese containing limit hydrolyzed soymilk. Food Sci. and Technol., 35 (8): 94-100.

Guinee, T.P. (2011). Cheese and cheese analogues. Encyclopedia of Dairy Sci., 814821.

Gunasekaran, S. and M.M. Ak. (2003). Measuring Cheese Stretchability. Pages 377-397 in Cheese Rheology and Texture. CRC Press, Boca Raton, FL.

Karimah, A. (2008). Browning characteristics of palm-based mozzarella analogues. Oil Palm Bulletin. (May): 29-40.

Wang, Y.C., K. Muthukumarappan, M.M. Ak, and S. Gunasekaran (1998). A device for evaluating melt/flow characteristics of cheeses.J. texture Studies, 29:43-55. 


\title{
إســتخـــام التقتيـــات الحـــيثــة لإنتـــاج الجبــن المـــوزاريــلا
}

\author{
تامرمحمد خالا حسن النجدى - محمد محمد مراد ـ محمود خطاب عفيفى

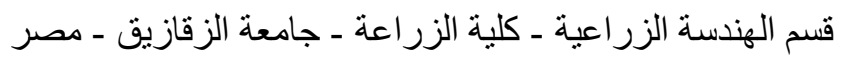

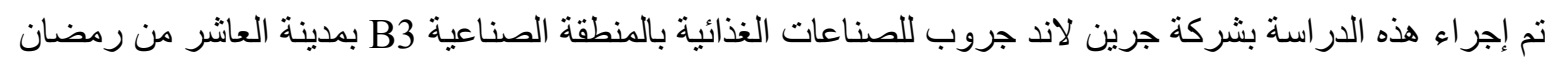

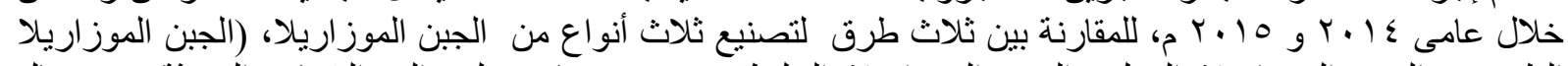

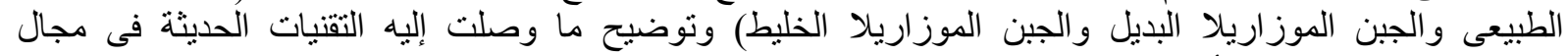

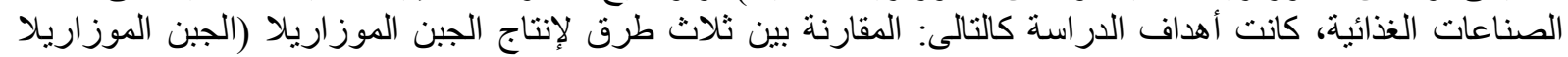

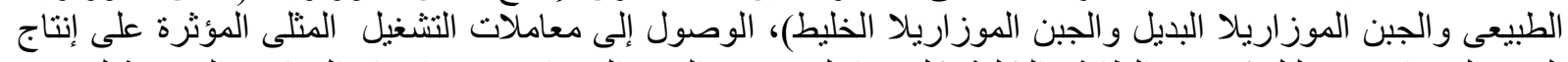

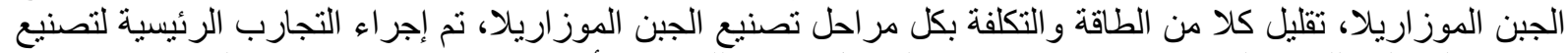

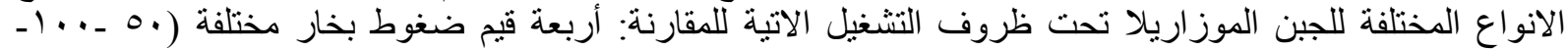

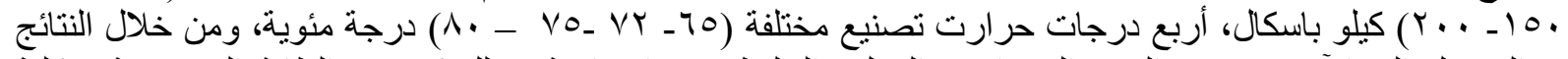

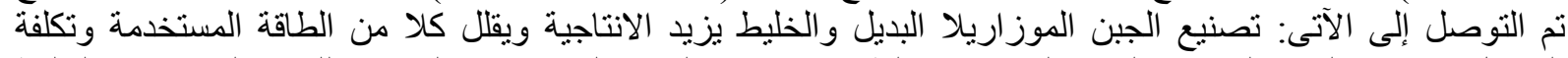

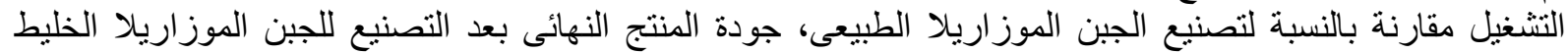

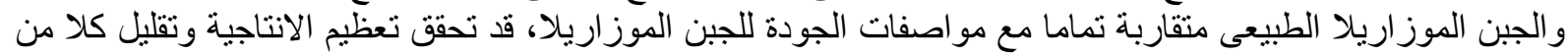

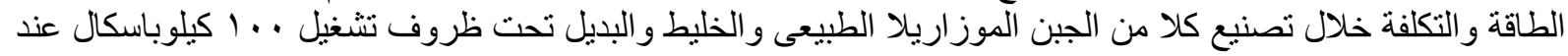

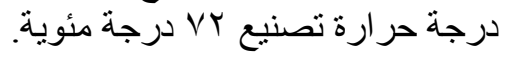

